\title{
Rationalization of Sewing Line and Workstation Layout Plan for Production of the Kimono Bathrobe
}

\author{
Sevim Yılmaz, Cumhur Çakman
}

\begin{abstract}
The apparel industry is one of the avant-garde sectors of Turkey and very important for the country's economy. In this study, work study was performed and the results were used for the balancing of sewing assembly line and for the optimization of workstation layout plan in the production of kimono bathrobe model in a factory in Denizli province of Turkey. According to done rationalization the efficiency of the balancing has been increased by $7,15 \%$ to $96,53 \%$. For the kimono order which was planned for 26 days of production, the number of workers required in the sewing line has been reduced by 2 persons and since the hourly rate is accepted $0.9 \$$ / hour, so as a total $442 \$$ was saved from the labor costs.
\end{abstract}

Index Terms-Work study, Balancing of sewing line, Workstation layout plan, Bathrobe

\section{INTRODUCTION}

In the last decade the labor prices in Turkey are increasing every year and this makes it more difficult for local producers to compete with Indian and China garment prices. Therefore, it is very important to rationalize production chain and for this purpose, it is very useful to optimize sewing assembly lines by work study. Most of researches performed on the optimization of assembly line are concentrated on the improving of computer programs by developing simulation models and are highly far to be realistic. In one of those studies performed in the east of Turkey, the simulation method was used to balance sewing assembly line, and according to the results of the study, the capacity utilization rate of the production line was increased by $25 \%$ [1]. In another study is applied a heuristic assembly line balancing technique known as "Probabilistic Line Balancing Technique", to solve multi- model assembly line balancing problem in a clothing company for five different models. There was shown that theoretically is possible to increase "Efficiency of the Balancing" for different pants models between $15,7-28 \%$ [2] . It is rather easy to make a program on the computer regarding the balancing of sewing assembly line, by accepting that all of workers can use all workstation machines or by changing the workers and work stations to make a balance on sewing line, but in reality, it is very difficult for the workers to adopt new methods or to use different new machines and, also it is hard to convince managers of a company to change the production method or to make corrections on sewing line. While investigating the

-Sevim Yılmaz, PhD, Pamukkale University, Denizli Vocational High School of Technical Sciences Textile, Clothing, Leather and Footwear Department, Denizli ,TURKIYE.

-Cumhur Çakman, PhD, Retired from Ege University, Textile Engineering Department, Izmir, TURKIYE. process of line balancing by work study in the company where the workers are mostly prime school educated people, you should be very careful and delicate with masters and managers, because when somebody do something for the development of the production capacity, they generally associate it with the loss of their job or position. A study on balance and optimization of knitted costume sewing assembly line was done by using industrial engineering technique to promote production efficiency; as the result the balance rate of the assembly line has been improved by $23 \%$ [3]. In a research study done by Gülseren Kurumer [4] , the kinds and amounts of contribution of activities occurring in work processes in clothing companies have been investigated, by applying multi-moment and long-time distribution time studies in six plants and by determining the percentage distribution of the activities defined, the weak points of the plants have been determined. In another study was investigated the problem of balancing assembly lines with heterogeneous workers while considering job rotation schedules and propose a hybrid algorithm that uses a Mixed Integer Programming (MIP) to select appropriate schedules from a pool of heuristically constructed solutions [5]. In a paper was proposed the parallel assignment method (PAM) for achieving a higher production rate [6]. Practical problems which cannot be solved by serial line balancing methods are provided and solved to explain the effectiveness of PAM. In this study are used data from part of master thesis, which was based on method development studies done in ready garment companies in the Aegean Region of Turkiye [7]. The current production method of kimono bathrobe in sewing line was studied by the trial and error method in the form presented by the band master and then was reorganized due to engineering studies.

\section{MATERIAL AND METHODS}

\section{A. Material}

The material of this study is the $\mathrm{M}$ size man (male) kimono bath robe model. Its specifications as a technical drawing are shown in Figure 1. Kimono model is made of terry towel fabric, it has 2 pockets and pockets are in patch shape. The model has its own fabric belt and the belt has 4 needle chain stitches. Company label and washing instruction is the only label and sewn in the centre of the back collar to centre the hanger.

\section{Methods}

Time measurements were made by chronometer with single time measurement method and REFA Standard Program was used for evaluation of measurements [8] . The basis of the REFA Standard Program on Evaluation of Time Measurements is as follows:

Step 1: Check whether the time measurement is correct and complete. 


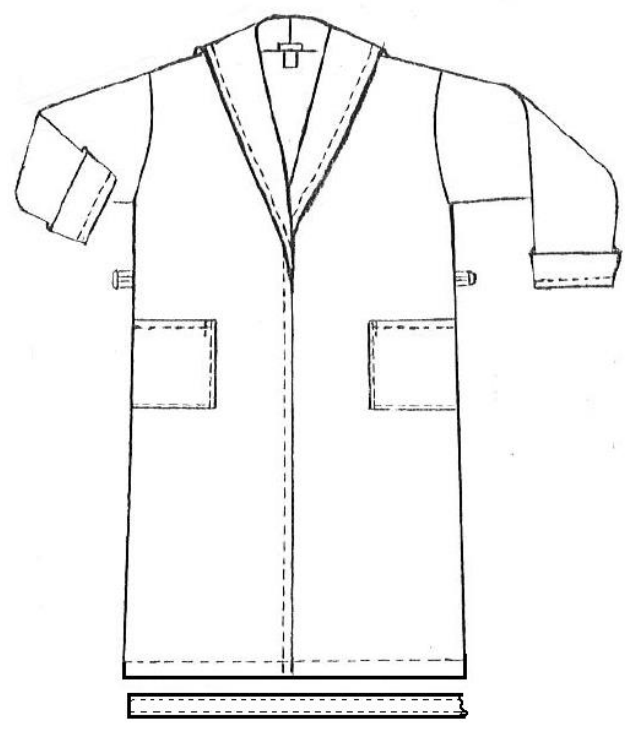

Figure 1. Male Kimono Bathrobe Model

Step 2: Calculation of real time.

Step 3: Statistical evaluation.

Step 4: Calculation of prescribed times (normal times if necessary)

Step 5: Collecting and transferring the prescribed times to the front page

Step 6: Determination of the unit time

$$
\mathrm{t}_{\mathrm{e}}: \mathrm{te}_{\mathrm{e}}=\mathrm{tg}_{\mathrm{g}}+\mathrm{t}_{\mathrm{v}}+\mathrm{ter}_{\mathrm{e}}
$$

6.1 determination of the base time $\mathrm{tg}_{\mathrm{g}}$

6.2 determination of the distribution time $\mathrm{t}_{\mathrm{v}}$

6.3 determination of the rest time ter

6.4 determination of other shares

6.5 determination of the given time te 1 , te 100 , te 1000 in minutes and hours

Work study was performed by observing the work done first. All operations and the work methods of the operators in the sewing process were determined by the work study. After the work study, the time study was performed and the duration of each operation done by the operators was measured in centiminutes. Measurements for each operation were carried out using a digital stopwatch. Measurements were made according to single time measurement method. The mean of the measurements was taken and the distribution plus the rest time were added as $23 \%$ to the base time (tg). In manual work operations, the time spent by workers for the transportation of goods was studied as the transportation was carried out irregularly at variable intervals. From $10 \%$ to $15 \%$ of the relevant operation time measured during the one-day run for different operators have been determined and this value was added to the base time at an average of $12 \%$.

Based on the data of work and time study, line balancing was revised and made more efficient; the transport time was shortened and proper material flow was achieved by rationalizing the machine layout. The confidence interval of the time data obtained by measurement was examined according to the "Number of Being Method" [8] and the number of studies was increased where necessary.

The Kimono Bathrobe Model studies for the related enterprise are calculated according to the following formulas:

Base time $($ Handwork $)=$ Actual time + Distribution times $=$ Measured Time $* 1,35$

Actual time $=$ Base time + Transportation time $=$ Measured time $* 1,12$

Transportation time $=0,12 *$ Measured Time

Distribution times $=0,23 *$ Measured Time

Base time $($ sewing $)=$ Actual time + Distribution times $=$ Measured time $* 1,23$

The Efficiency of the Balancing =

$$
=\frac{\text { Capacity } * \text { Total operation time } * 100}{\text { Number of the workers } * \text { Daily working time }}
$$

When the time measurements are applied through a specific method, the evaluation of the time measurements must be done. In this aspect in this study for line balancing and optimization of workstation settlement plan, "The Six Step Evaluation Method" that REFA has specified was applied $[8,9]$

\section{RESULTS AND DISCUSSION}

A. Revealing the numerical expression of existing and reorganized line balancing after the work study

According to the current working method in the enterprise, there is free time in the workflow. In Table 1, the free time of the operators is given in bold in the "Free Time" column. The total of these free times is 1459 minutes, which is equivalent to 24.27 hours. In the band, it is possible to sew 100 (1459: $14,48=100,75)$ kimonos theoretically in case of a good line balancing and zero free time. When we calculate the efficiency of the current balancing:

Daily production capacity: 850 number / day

Daily working time: 510 minute/day

Total operation time: 14,48 minute

Total number of workers: 27

The Efficiency of the Balancing = $850 * 14,48 * 100$

$=$
$=89,38 \%(6) \quad 27 * 510$

The abbreviations used in this study are as following:

Table 1. Work Study of Company's Current Situation in the Kimono Bathrobe Production and Line Balancing. Source: own research results 


\begin{tabular}{|c|c|c|c|c|c|c|c|c|c|c|}
\hline $\begin{array}{c}\text { Opn } \\
\mathrm{Nr}\end{array}$ & Opn Name & $\mathbf{T M}$ & $\begin{array}{c}\mathbf{t g} \\
(\mathrm{min})\end{array}$ & $\begin{array}{l}\text { DPQ } \\
(\mathrm{min})\end{array}$ & NT & NNMW & $\begin{array}{l}\text { Op. } \\
\text { Nr. }\end{array}$ & $\begin{array}{c}\text { LT } \\
(\mathbf{m i n})\end{array}$ & $\begin{array}{l}\operatorname{Pr} \\
(\%)\end{array}$ & $\begin{array}{l}\text { MOT } \\
(\mathrm{cmin})\end{array}$ \\
\hline \multirow[t]{2}{*}{1} & \begin{tabular}{|l|} 
Getting of body parts \\
together and regulation
\end{tabular} & HW & 0,74 & 600 & 441 & 0,87 & 1 & 69 & 85 & 54,50 \\
\hline & & & 0,74 & 250 & 184 & 0,36 & 2 & 326 & 85 & 54,50 \\
\hline \multirow[t]{2}{*}{2} & Marking of pocket place & HW & 0,62 & 820 & 509 & 1,00 & 3 & 1 & 85 & 46,00 \\
\hline & & & 0,62 & 30 & 19 & 0,04 & 2 & 307 & 85 & 46,00 \\
\hline 3 & Pocket edge stitching & 5TOSM & 0,33 & 850 & 280 & 0,55 & 4 & 230 & 80 & 26,80 \\
\hline 4 & Pocket ironing & $\mathrm{HI}$ & 0,52 & 850 & 439 & 0,86 & 5 & 71 & 80 & 42,00 \\
\hline 5 & Pocket mount seaming & LSM & 0,34 & 850 & 293 & 0,57 & 6 & 217 & 90 & 28,00 \\
\hline \multirow[t]{2}{*}{6} & Pocket assembly & LSM & 0,62 & 810 & 506 & 0,99 & 7 & 4 & 80 & 50,80 \\
\hline & & & 0,62 & 40 & 25 & 0,05 & 8 & 485 & 80 & 50,80 \\
\hline 7 & Pocket mount pressure & LSM & 0,59 & 850 & 504 & 0,99 & 9 & 6 & 70 & 48,20 \\
\hline 8 & Arm edge stitching & 5TOSM & 0,31 & 850 & 262 & 0,51 & 10 & 248 & 80 & 25,10 \\
\hline \multirow[t]{2}{*}{9} & $\begin{array}{l}\text { Shoulder seaming and arm } \\
\text { affixing }\end{array}$ & 5TOSM & 0,78 & 650 & 509 & 1,00 & 11 & 1 & 100 & 63,70 \\
\hline & & & 0,78 & 200 & 157 & 0,31 & 4 & 77 & 100 & 63,70 \\
\hline \multirow[t]{2}{*}{10} & Shoulder and arm pressure & LSM & 0,82 & 610 & 503 & 0,99 & 12 & 7 & 100 & 67,00 \\
\hline & & & 0,82 & 240 & 198 & 0,39 & 6 & 19 & 100 & 67,00 \\
\hline \multirow[t]{2}{*}{11} & Arm and side seaming & 5TOSM. & 1,02 & 425 & 434 & 0,85 & 13 & 76 & 100 & 83,00 \\
\hline & & & 1,02 & 425 & 434 & 0,85 & 14 & 76 & 100 & 83,00 \\
\hline \multirow[t]{2}{*}{12} & Lapel affixing & 5TOSM. & 0,65 & 780 & 504 & 0,99 & 15 & 6 & 110 & 52,50 \\
\hline & & & 0,65 & 70 & 45 & 0,09 & 16 & 465 & 110 & 52,50 \\
\hline \multirow[t]{2}{*}{13} & Lapel pressure & LSM & 0,76 & 665 & 507 & 0,99 & 17 & 3 & 105 & 62,00 \\
\hline & & & 0,76 & 185 & 141 & 0,28 & 8 & 344 & 105 & 62,00 \\
\hline 14 & Hemming stitch & 5TOSM & 0,38 & 850 & 326 & 0,64 & 16 & 139 & 105 & 31,20 \\
\hline 15 & $\begin{array}{l}\text { Marking of belt-loop } \\
\text { place }\end{array}$ & HW & 0,60 & 850 & 509 & 1,00 & 18 & 1 & 70 & 44,40 \\
\hline 16 & $\begin{array}{l}\text { Preparation of tab and } \\
\text { belt-loop }\end{array}$ & BLM & 0,06 & 850 & 47 & 0,09 & 10 & 201 & 100 & 4,50 \\
\hline 17 & $\begin{array}{l}\text { Cutting of tab and belt- } \\
\text { loop }\end{array}$ & HW & 0,15 & 850 & 125 & 0,25 & 10 & 76 & 80 & 12,00 \\
\hline \multirow[t]{2}{*}{18} & $\begin{array}{l}\text { Stitching of belt-loop to } \\
\text { side }\end{array}$ & LSM & 1,03 & 425 & 438 & 0,86 & 19 & 72 & 70 & 83,80 \\
\hline & & & 1,03 & 425 & 438 & 0,86 & 20 & 72 & 70 & 83,80 \\
\hline \multirow[t]{2}{*}{19} & $\begin{array}{l}\text { Skirt and arm hem } \\
\text { bending }\end{array}$ & LSM & 1,06 & 425 & 451 & 0,88 & 21 & 59 & 100 & 86,20 \\
\hline & & & 1,06 & 425 & 451 & 0,88 & 22 & 59 & 100 & 86,20 \\
\hline 20 & Belt edge stitching & LSM & 0,22 & 850 & 187 & 0,37 & 8 & 157 & 75 & 17,90 \\
\hline 21 & $\begin{array}{l}\text { Belt } 4 \text { needle chain } \\
\text { seaming }\end{array}$ & 9NCSM & 0,50 & 850 & 424 & 0,83 & 23 & 86 & 100 & 40,60 \\
\hline \multirow[t]{4}{*}{22} & $\begin{array}{l}\text { Preliminary quality } \\
\text { control }\end{array}$ & HW & 2,37 & 212 & 502 & 0,98 & 24 & 8 & 100 & 175,5 \\
\hline & & & 2,37 & 213 & 505 & 0,99 & 25 & 5 & 85 & 175,5 \\
\hline & & & 2,37 & 212 & 502 & 0,98 & 26 & 8 & 85 & 175,5 \\
\hline & & & 2,37 & 213 & 505 & 0,99 & 27 & 5 & 85 & 175,5 \\
\hline \multicolumn{3}{|c|}{ Total Sewing Time / Number : } & 14,48 & Total Lo & Time & : & & 1459 & & \\
\hline
\end{tabular}

Operation number - Opn $\mathrm{Nr}$

Name of the operation - Opn Name

Type of the machine - TM

Base time (minute) - $\operatorname{tg}(\mathrm{min})$

Daily production quantity -DPQ

Necessary time (minute) - NT (min)

Necessary number of machinery and workers - NNM

Operator number - $\mathrm{Op} \mathrm{Nr}$

Lost time - LT

Performance - Pr

Measured operation time (centiminute) - MOT (cmin)
Hand Iron - HI

Handwork - HW

Belt-loop machine - BLM

Five tread over lock machine - 5TOSM

Lock stitch machine - LSM

Nine needle chain stitch machine - 9 NCSM

Preliminary quality control - PQC

Total base time (minute) - TBT (min) 
B. Calculating the Necessary Number of Machinery and Workers

The data related to the machine-based operation times according to the current work flow in the enterprise are given in Table 2, while the machine layout is shown in Figure 2. Based on these data, the sum of the operation times and the theoretical machinery and workers' requirements according to the machine types were calculated and the results are shown in Table 3 . The number of machines (and workers) required is calculated according to the following equation:

Number of the required machinery (and workers $)=($ Total operation time * Number of daily production) / Daily working time (7)

Table 2. Theorically Necessary Number of Machinery and Workers in the Current Production of the Kimono Bathrobe Line. Source: own research results

\begin{tabular}{|c|c|c|c|c|}
\hline TM & Opn $\mathrm{Nr}$ & $\operatorname{tg}(\min )$ & TBT(min) & NNMW \\
\hline $\mathrm{HI}$ & 4 & 0,52 & 0,52 & 0,9 \\
\hline 9NCSM & 21 & 0,5 & 0,5 & 0,8 \\
\hline \multirow[t]{6}{*}{5 TOSM } & 3 & 0,33 & & \\
\hline & 8 & 0,31 & & \\
\hline & 9 & 0,78 & & \\
\hline & 11 & 1,02 & & \\
\hline & 12 & 0,65 & & \\
\hline & 14 & 0,38 & 3,47 & 5,8 \\
\hline BLM & 16 & 0,06 & 0,06 & 0,1 \\
\hline \multirow[t]{5}{*}{ HW } & 1 & 0,74 & & \\
\hline & 2 & 0,62 & & \\
\hline & 15 & 0,60 & & \\
\hline & 17 & 0,15 & & \\
\hline & 22 & 2,37 & 4,48 & 7,5 \\
\hline \multirow[t]{8}{*}{ LSM } & 5 & 0,34 & & \\
\hline & 6 & 0,62 & & \\
\hline & 7 & 0,59 & & \\
\hline & 10 & 0,82 & & \\
\hline & 13 & 0,76 & & \\
\hline & 18 & 1,03 & & \\
\hline & 19 & 1,06 & & \\
\hline & 20 & 0,22 & 5,44 & 9,1 \\
\hline
\end{tabular}

C. The Necessary Number of Machinery and Workers Required after Reorganization of Line Balancing and Machine Settlement Plan

The data related to the situation after rationalization of line balancing and machine layout plan are given in Table 4 .
Table 3 shows the need for machinery and workers, calculated from the data in Table 4 .

Table 3. The Need of Total Machinery and Workers in Kimono Bathrobe Band After Arrangement of Line Balancing and Machine Settlement Plan. Source: own research results

\begin{tabular}{|l|l|l|l|}
\hline \multicolumn{2}{|l|}{$\begin{array}{l}\text { Necessary number of } \\
\text { machinery }\end{array}$} & $\begin{array}{l}\text { Necessary number of } \\
\text { Workers }\end{array}$ \\
\hline Machines & pieces & Workers & pieces \\
\hline LSM & 9 & LSM & 9 \\
\hline 5TOSM & 5 & 5TOSM & 6 \\
\hline BLM & 1 & BLM+9NCSM & 1 \\
\hline HI & 1 & HI & 1 \\
\hline 9NCSM & 1 & HW & 8 \\
\hline Total & $\mathbf{1 7}$ & Total & $\mathbf{2 5}$ \\
\hline
\end{tabular}

As a result of the work and time studies conducted, it was not possible to determine the inappropriate and unnecessary movements in the internal work flow, but it was observed that the workload of some machinists and insurers was insufficient and caused the monetary losses which increased the cost. A more rational new line balancing study is proposed to eliminate this insufficient workload. As a result of the rationalization studies in this study method, it is seen that the labor demand decreased from 27 to 25 in the current line balancing. With the change of method, production time per total unit is not shortened and there is no change in the need for theoretical workers and machinery.

D. Rationalization Study on Worker and Machine Settlement Plan in the Kimono Bathrobe Production

In the creation of the machine and worker settlement plan, the worker and machine settlement should be made in the shortest way possible to transfer the material and follow the order of operation in the work flow.

The machine and worker settlement suitable for the work flow in the existing line balancing in the production of kimono bathrobes is given in Figure 2. The proposed worker and machine settlement following the work study is given in Figure 3. With new settlement, the principle of making the material transfer in the shortest way and with the least time wasting is considered.

By line balancing the number of workers has been reduced providing more efficient use of the existing workers. The total number of operators has been reduced from 27 to 25 . Total production time per piece has not been changed. The number of machines used was also reduced by 2 , one lock stitch machine and one 5 thread overlock machine were even fallen into abeyance. Workers and machines that were removed from kimono bathrobe production can be used in sewing operations related to another product 
Figure 2. Workstation Settlement Plan in the Production of Kimono Bathrobe Before Work Study

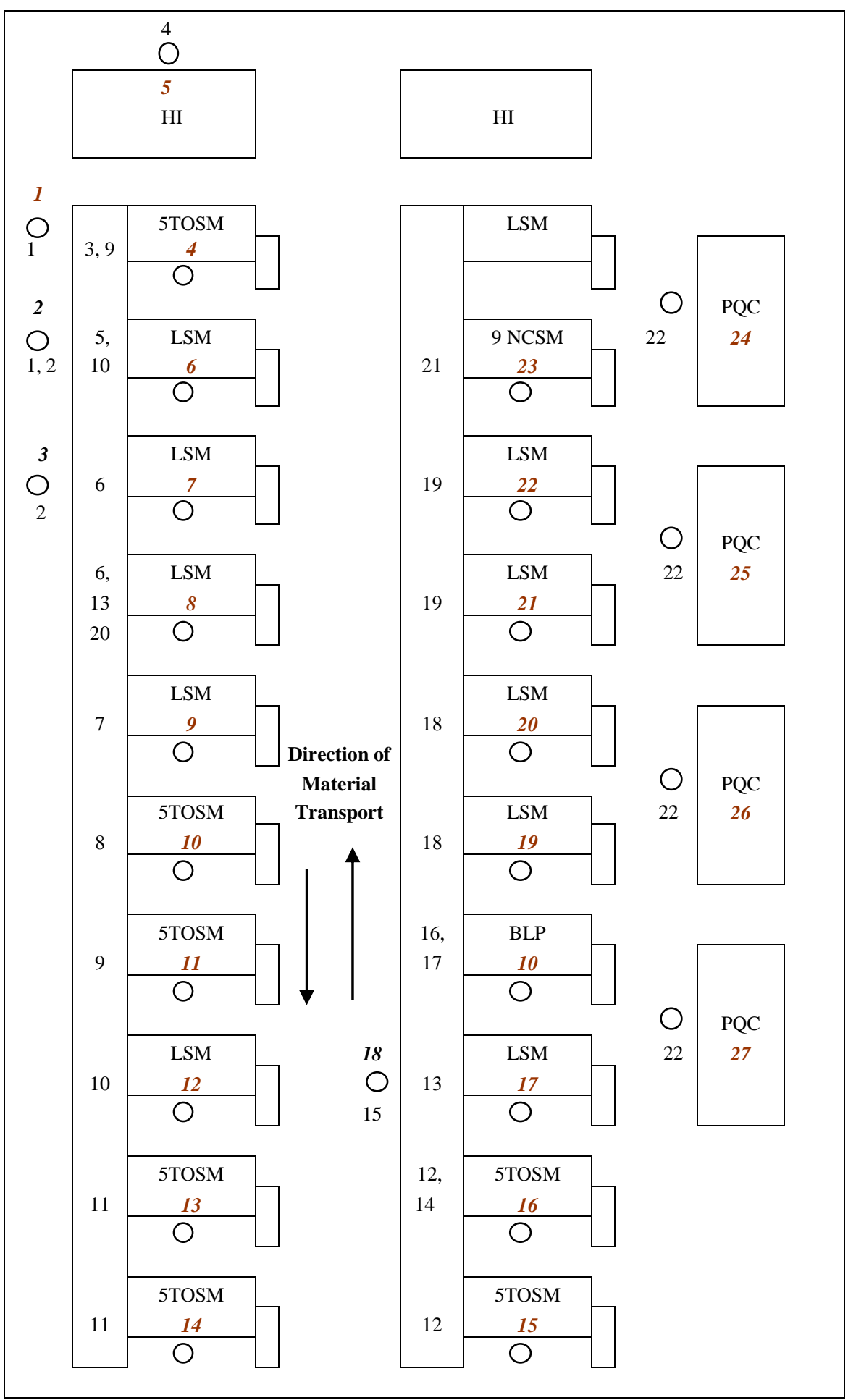


Figure 3. Workstation Settlement Plan in the Production of Kimono Bathrobe After Work Study

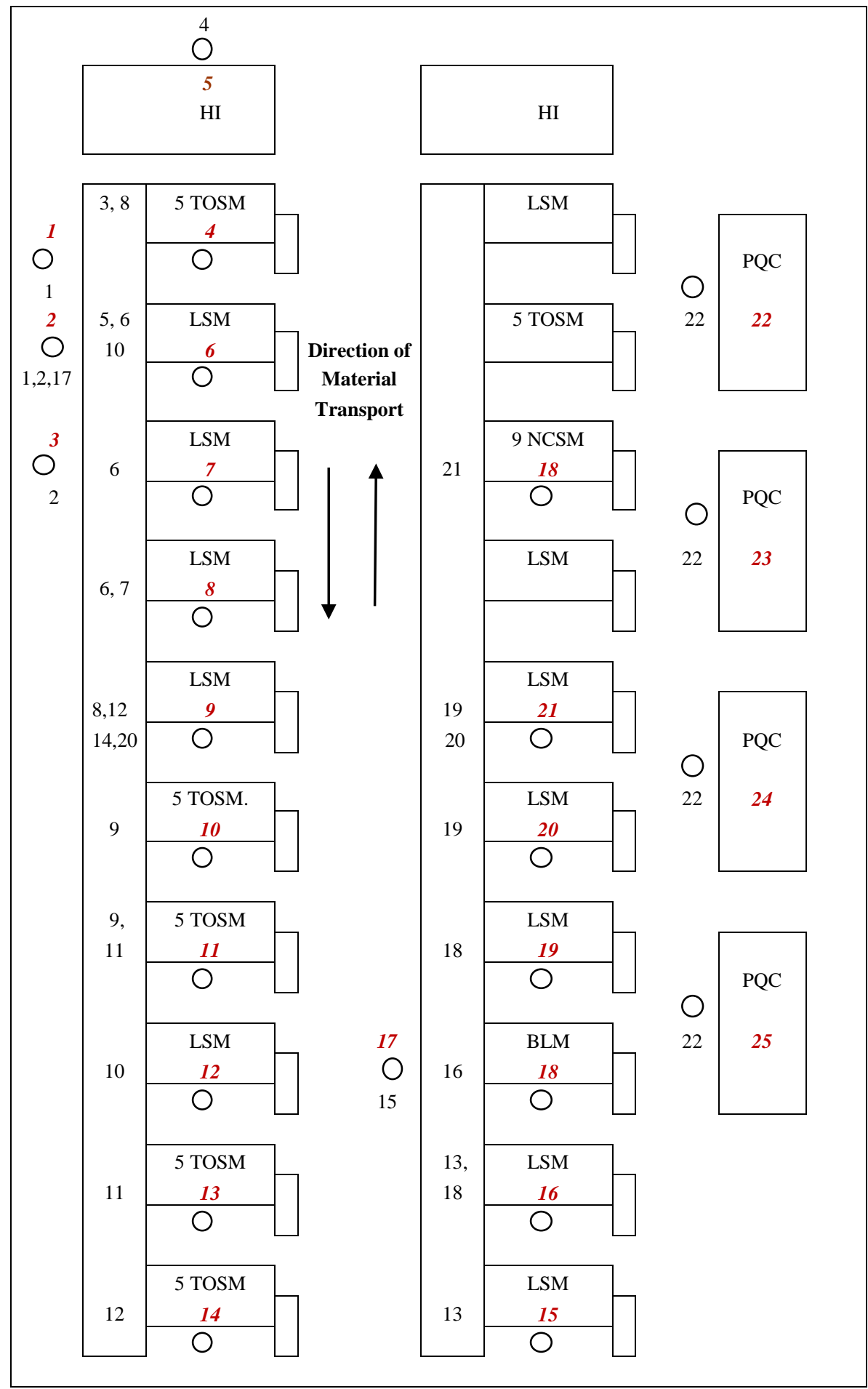

E. Line Balancing After Work Studies and Rationalization of Workstation Settlement Plan in the Kimono Bathrobe Production

As seen from the data in Table 1 and Table 4, with the rationalization applications the balancing efficiency was increased with the new line balancing, while the sewing time did not change.
The efficiency of balancing after engineering based line balancing studies is as follows.

The Efficiency of the Balancing $\%=(850 * 14,48 / 25 *$ 510) $* 100=96,53 \%$ 
Table 4. Line Balancing After Work Study and Rationalization of Workstation Settlement Plan in the Kimono Bathrobe Production. Source: own research results

\begin{tabular}{|c|c|c|c|c|c|c|c|c|c|c|}
\hline $\begin{array}{c}\text { Opn } \\
\mathrm{Nr}\end{array}$ & Opn Name & TM & $\begin{array}{c}\mathbf{t}_{\mathbf{g}} \\
(\mathbf{m i n})\end{array}$ & $\begin{array}{l}\text { DPQ } \\
\text { (min) }\end{array}$ & NT & NNMW & $\begin{array}{l}\text { Op. } \\
\text { Nr. }\end{array}$ & $\begin{array}{c}\text { LT } \\
(\mathbf{m i n})\end{array}$ & $\begin{array}{l}\operatorname{Pr} \\
(\%) \\
\end{array}$ & $\begin{array}{l}\text { MOT } \\
(\mathrm{cmin})\end{array}$ \\
\hline 1 & $\begin{array}{l}\text { Getting of body parts } \\
\text { together and regulation }\end{array}$ & HW & 0,74 & 695 & 511 & 1,00 & 1 & 1 & 85 & 54,5 \\
\hline & & & 0,74 & 155 & 114 & 0,22 & 2 & 396 & 85 & 54,5 \\
\hline \multirow[t]{2}{*}{2} & $\begin{array}{l}\text { Marking of pocket } \\
\text { place }\end{array}$ & HW & 0,62 & 820 & 509 & 1,00 & 3 & 1 & 85 & 46,0 \\
\hline & & & 0,62 & 30 & 19 & 0,04 & 2 & 377 & 85 & 46,0 \\
\hline 3 & Pocket edge stitching & 5TOSM & 0,33 & 850 & 280 & 0,55 & 4 & 230 & 80 & 26,8 \\
\hline 4 & Pocket ironing & $\mathrm{HI}$ & 0,52 & 850 & 439 & 0,86 & 5 & 71 & 80 & 42,0 \\
\hline 5 & Pocket mount seaming & LSM & 0,34 & 850 & 293 & 0,57 & 6 & 217 & 90 & 28,0 \\
\hline \multirow[t]{2}{*}{6} & Pocket assembly & LSM & 0,62 & 815 & 509 & 1,00 & 7 & 1 & 80 & 50,8 \\
\hline & & & 0,62 & 35 & 22 & 0,04 & 6 & 195 & 80 & 50,8 \\
\hline 7 & Pocket mount pressure & LSM & 0,59 & 850 & 504 & 0,99 & 8 & 6 & 70 & 48,2 \\
\hline \multirow[t]{2}{*}{8} & Arm edge stitching & 5TOSM & 0,31 & 740 & 228 & 0,45 & 4 & 2 & 80 & 25,1 \\
\hline & & & 0,31 & 110 & 34 & 0,07 & 9 & 476 & 80 & 25,1 \\
\hline \multirow[t]{2}{*}{9} & $\begin{array}{l}\text { Shoulder seaming and } \\
\text { arm affixing }\end{array}$ & 5TOSM & 0,78 & 650 & 509 & 1,00 & 10 & 1 & 100 & 63,7 \\
\hline & & & 0,78 & 200 & 157 & 0,31 & 11 & 353 & 100 & 63,7 \\
\hline \multirow[t]{2}{*}{10} & $\begin{array}{l}\begin{array}{l}\text { Shoulder and arm } \\
\text { pressure }\end{array} \\
\end{array}$ & LSM & 0,82 & 618 & 509 & 1,00 & 12 & 1 & 100 & 67,0 \\
\hline & & & 0,82 & 232 & 191 & 0,37 & 6 & 4 & 100 & 67,0 \\
\hline \multirow[t]{2}{*}{11} & Arm and side seaming & 5TOSM. & 1,02 & 500 & 510 & 1,00 & 13 & 0 & 100 & 83,0 \\
\hline & & & 1,02 & 350 & 357 & 0,70 & 11 & 4 & 100 & 83,0 \\
\hline \multirow[t]{2}{*}{12} & Lapel affixing & 5TOSM. & 0,65 & 790 & 510 & 1,00 & 14 & 0 & 110 & 52,5 \\
\hline & & & 0,65 & 60 & 39 & 0,08 & 9 & 437 & 110 & 52,5 \\
\hline \multirow[t]{2}{*}{13} & Lapel pressure & LSM & 0,76 & 665 & 507 & 0,99 & 15 & 3 & 105 & 62,0 \\
\hline & & & 0,76 & 185 & 141 & 0,28 & 16 & 369 & 105 & 62,0 \\
\hline 14 & Skirt hem stitching & 5TOSM & 0,38 & 850 & 326 & 0,64 & 9 & 111 & 105 & 31,2 \\
\hline 15 & $\begin{array}{l}\text { Marking of belt-loop } \\
\text { place }\end{array}$ & HW & 0,60 & 850 & 509 & 1,00 & 17 & 1 & 70 & 44,4 \\
\hline 16 & $\begin{array}{l}\text { Preparation of tab and } \\
\text { belt-loop }\end{array}$ & BLM & 0,06 & 850 & 47 & 0,09 & 18 & 463 & 100 & 4,5 \\
\hline 17 & $\begin{array}{l}\text { Cutting of tab and belt- } \\
\text { loop }\end{array}$ & HW & 0,15 & 850 & 125 & 0,25 & 2 & 252 & 80 & 12,0 \\
\hline \multirow[t]{2}{*}{18} & $\begin{array}{l}\text { Stitching of belt-loop } \\
\text { to side }\end{array}$ & LSM & 1,03 & 495 & 510 & 1,00 & 19 & 0 & 70 & 83,8 \\
\hline & & & 1,03 & 355 & 366 & 0,72 & 16 & 3 & 70 & 83,8 \\
\hline \multirow[t]{2}{*}{19} & $\begin{array}{l}\text { Skirt and arm hem } \\
\text { bending }\end{array}$ & LSM & 1,06 & 480 & 509 & 1,00 & 20 & 1 & 100 & 86,2 \\
\hline & & & 1,06 & 370 & 392 & 0,77 & 21 & 118 & 100 & 86,2 \\
\hline \multirow[t]{2}{*}{20} & Belt edge stitching & LSM & 0,22 & 520 & 114 & 0,22 & 21 & 4 & 75 & 17,9 \\
\hline & & & 0,22 & 330 & 73 & 0,14 & 9 & 38 & 75 & 17,9 \\
\hline 21 & $\begin{array}{l}\text { Belt } 4 \text { needle chain } \\
\text { seaming }\end{array}$ & 9NCSM & 0,50 & 850 & 424 & 0,83 & 18 & 39 & 100 & 40,6 \\
\hline \multirow[t]{4}{*}{22} & $\begin{array}{l}\text { Preliminary quality } \\
\text { control }\end{array}$ & HW & 2,37 & 212 & 502 & 0,98 & 22 & 8 & 85 & 175,5 \\
\hline & & & 2,37 & 213 & 505 & 0,99 & 23 & 5 & 85 & 175,5 \\
\hline & & & 2,37 & 213 & 505 & 0,99 & 24 & 5 & 85 & 175,5 \\
\hline & & & 2,37 & 212 & 502 & 0,98 & 25 & 8 & 85 & 175,5 \\
\hline \multicolumn{3}{|c|}{ Total Sewing Time / Number : } & 14,48 & & Cotal Los & t Time : & & 565 & & \\
\hline
\end{tabular}




\section{CONCLUSION}

As a result of the work study and line balancing, the efficiency of the balancing has been increased by $7,15 \%$ from $89,38 \%$ to $96,53 \%$. The number of workers required in the sewing line has been reduced by 2 persons. Monetary savings in the measured time, since the hourly rate is $1 \$$ / hour and 8.5 hours $* 1 \$ * 2$ person per day are $17 \$$. The kimono order was planned for 26 days of production, so as a total for 26 days $* 17 \$=442 \$$ was saved from the labor costs. Total free time is decreased from 1459 min to $565 \mathrm{~min}$ and the lost time was reduced about 2.6 times. It has been shown that the line balancing in the standard products such as kimono bathrobes developed by the masters who have more than 15 years of experience can be made more efficient with the engineering works and that the labor costs of the enterprise can be decreased.

The benefits of using work study and line balancing technique in the bathrobe production can be summarized as follows:

1- Thanks to the rise in the capacity, the demands of the customers can be satisfied faster and more orders can be taken.

2- The enhancements in the company's layout and proving data to the planning department makes it possible to do realistic plans, to decrease the extra shifts (overtime) and thus, to reduce the cost per unit.

3- As a result of a neat and regular work, it is possible to improve the image of the company through increasing the quality of the service offered.

4- With the rise of the company's image, it is possible to increase the competitiveness and sell goods with higher profit margins.
5- By lowering the costs per unit, it is possible to attract the potential orders more easily to the company or to prevent from being passed to the alternative manufacturers.

Today's competitive conditions require the garment industry to take the necessary precautions. The garment companies for which it is possible to increase the competition power by preventing the waste of materials and labor, should do firstly that disposal works .

\section{REFERENCES}

[1]. Aslan, Ş., Akdağ, R., Yıldırım, A., Implication of Assembly Line Balancing by Using Simulation Method in a Textile Manufacturing Firm, Social Sciences Studies Journal. 2017; 3(7): 1355-1365

[2]. Eryürük, S., Kalaoğlu, F., Baskak M., Assembly Line Balancing by Using Statistical Method in Clothing Production. Journal of Textile and Apparel. 2011; 21(1):65-71

[3]. Wang W., Study on Balance and Optimization of Knitted Costume Sewing Assembly Line, Applied Mechanics and Materials, 2012; 101102: 822-827

[4]. Kurumer G., Investigating The Contributions to Basic T1me of the Activities Which Affect The Productivity in Clothing Plants, Tekstil ve Mühendis, 1996;10 (53-54):19-26

[5]. Akag1,F., Osaki,H., Kikuchi, S., A Method for Assembly Line Balancing with More Than One Worker in Each Station , International Journal of Production Research, 1983; 21:5, 755770, DOI: 10.1080/00207548308942409

[6]. M.C.O., Moreira, A.M. Costa, Hybrid Heuristics for Planning Job Rotation Schedules in Assembly Lines with Heterogeneous Workers, International Journal of Production Economics, 2013; 141 (2): 552-560

[7]. Yılmaz, S., Dikim İşlemlerinde Metot Geliştirme Araştırmaları. Yüksek Lisans Tezi, Ege Üniversitesi, Fen Bilimleri Enstütüsü; 2011 May, 159 $\mathrm{p}$.

[8]. REFA Metodenlehre des Arbeitsstudiums Teil 2, "Datenermittlung"; 1984

[9]. Güner, M., Tekstil ve Konfeksiyonda İş Etüdü . E. Ü. Tekstil ve Konfeksiyon Araştırma -Uygulama Merkezi ; 2013 